\title{
En kvinne med residiverende feber, tørrhoste og ascites
}

NOE Å LAERE AV

\section{PAUL ANDERS SLETTEN OLSEN}

E-post:paanol@vestreviken.no Avdeling for fordøyelses- og leversykdommer

St. Olavs hospital

*Nåværende adresse:

Medisinsk avdeling

Bærum sykehus

Paul Anders Sletten Olsen (f. 1987) er lege i spesialisering i indremedisin. Forfatter har fylt ut ICMJE-skjemaet og oppgir ingen interessekonflikter.

\section{PETTER QUIST-PAULSEN}

Avdeling for blodsykdommer

St. Olavs hospital

Petter Quist-Paulsen (f. 1969) er ph.d., spesialist i indremedisin og i hematologi, universitetslektor I og overlege.

Forfatter har fylt ut ICMJE-skjemaet og oppgir ingen interessekonflikter.

\section{ROBERT BRUDEVOLD}

Medisinsk avdeling

Ålesund sjukehus

Robert Brudevold (f. 1958) er spesialist i indremedisin og i hematologi og seksjonsoverlege.

Forfatter har fylt ut ICMJE-skjemaet og oppgir ingen interessekonflikter.

\section{ALEKSEI OGARKOV}

Klinikk for bildediagnostikk

St. Olavs hospital

Aleksei Ogarkov (f. 1975) er spesialist i radiologi og overlege.

Forfatter har fylt ut ICMJE-skjemaet og oppgir ingen interessekonflikter.

\section{ØYSTEIN BRENNA}

Avdeling for fordøyelses- og leversykdommer

St. Olavs hospital

**Nåværende adresse:

Seksjon for fordøyelsessykdommer

Sykehuset Levanger

Øystein Brenna (f. 1975) er ph.d., spesialist i indremedisin og i fordøyelsessykdommer og overlege.

Forfatter har fylt ut ICMJE-skjemaet og oppgir ingen interessekonflikter.

Feber, hoste og forhøyede inflammasjonsparametere gir mistanke om pneumoni. Men når det også foreligger ascites og bemerkelsesverdige, radiologiske funn fra flere 
organsystemer, bør flere differensialdiagnoser vurderes. En bred utredning kan være nødvendig for å stille rett diagnose. I dette tilfellet viste det seg å være en sjelden og lite kjent tilstand.

En kvinne i 6o-årene oppsøkte lege med symptomer på dyp venetrombose (DVT) etter en venstresidig ankelfraktur. Hun hadde glaukom, hypertensjon og hyperkolesterolemi fra tidligere. Dyp venetrombose ble bekreftet med ultralydundersøkelse, og det ble samtidig funnet trombocytemi med en trombocyttverdi på $1026 \cdot 10^{9} / 1$ (145-390). Hun hadde i tillegg leukocytose med leukocyttverdi på 12,3 $10^{9} / 1(3,7-10,0)$, mens hemoglobinnivået var 13,8 g/100 ml (11,7-15,3). Videre utredning påviste JAK2-V617F-mutasjon, og diagnosen essensiell trombocytose ble stilt. Det ble startet behandling med hydroksyurea og antikoagulasjonsmidler etter gjeldende retningslinjer.

Til tross for behandlingen hadde pasienten vedvarende hevelse i venstre underekstremitet, og det ble utført CT-venografi. I tillegg til ødemer som strakte seg opp til låret, viste undersøkelsen uttalt ødem i intraabdominalt fettvev, markerte lymfeknuter i lysken og mesenteriet og reaktive forandringer rundt flere bukorganer, inkludert nyrene. Den påfølgende utredningen inkluderte flere radiologiske undersøkelser, som ikke ga noen diagnostisk avklaring, og en biopsi fra intraabdominalt fettvev, som kun viste akkumulering av makrofager. Pasienten hadde på dette tidspunktet ingen plager, og utredningen ble derfor avsluttet med den tentative diagnosen posttrombotisk syndrom etter dyp venetrombose og essensiell trombocytose.

Venøs tromboembolisme, som omfatter dyp venetrombose og lungeemboli, er en vanlig diagnose både i allmennpraksis og på sykehus. De vanligste risikofaktorene for slik sykdom er arvelig trombofili, malignitet, immobilisering, traume, graviditet, bruk av østrogener, tidligere venøs tromboembolisme og antifosfolipidsyndrom $(1,2)$. Det er også en assosiasjon mellom tromboser, både arterielle og venøse, og essensiell trombocytose (3), som hos vår pasient. Posttrombotisk syndrom - kjennetegnet av blant annet smerter, tunghetsfølelse, ødemer, rubor og varicer - oppstår hos omtrent $20-50$ \% av pasientene med venøs tromboembolisme og er den vanligste senkomplikasjonen ved dyp venetrombose (4). Vår pasient hadde flere funn som ikke passet med et klassisk posttrombotisk bilde. Kliniske funn kan imidlertid være uspesifikke og variable, og en sikker diagnostisk avklaring kan være utfordrende.

Mutasjoner i IAK2-genet er viktig i patogenesen ved flere myeloproliferative neoplasier. Mutasjonen gjør at de hematopoetiske cellene blir mer følsomme for vekstfaktorer som erytropoietin og trombopoietin, som fører til økt celleproliferasjon og potensiell malignitetsutvikling. Mutasjonen er påvist i nærmest alle tilfeller av polycythaemia vera, mens den er til stede hos omkring 50-60\% av pasientene med essensiell trombocytose og primær myelofibrose (5). Kronisk myelogen leukemi, den fjerde av de myeloproliferative neoplasiene, har ikke samme assosiasjon med JAK2-mutasjonen, men kjennetegnes ved det såkalte Philadelphia-kromosomet (6).

Ett år senere fikk pasienten residiverende og langvarige episoder med feber og tørrhoste. På mistanke om pneumoni ble hun behandlet med gjentatte kurer med ulike antibiotika, men med ingen eller kortvarig effekt. Etter hvert ble hun økende dyspneisk, det tilkom ascites og hun ble innlagt ved lokalsykehuset for videre utredning. Det ble på nytt utført CT abdomen, supplert med MR bekken og CT thorax, som fortsatt viste reaktive forandringer som tidligere, men nå også fortykkelse av pleura og perikard. Blodkultur, urindyrkning og nasopharynxprøve var uten funn. Bronkoskopi med bronkoalveolær lavage var negativ med tanke på infeksiøse agens, mens cytologi av ascitesvæsken viste makrofager. Det var ingen mistanke om autoimmun sykdom, og gynekolog fant ingen holdepunkter for gynekologisk cancer.

CT abdomen-bildene ble oversendt til et universitetssykehus for ny vurdering. Radiologen bemerket påfallende forandringer rundt nyrene (fig 1 ) - et funn som tydet på såkalte hårete nyrer (hairy kidneys). Pasienten ble overført til universitetssykehuset for videre utredning. 


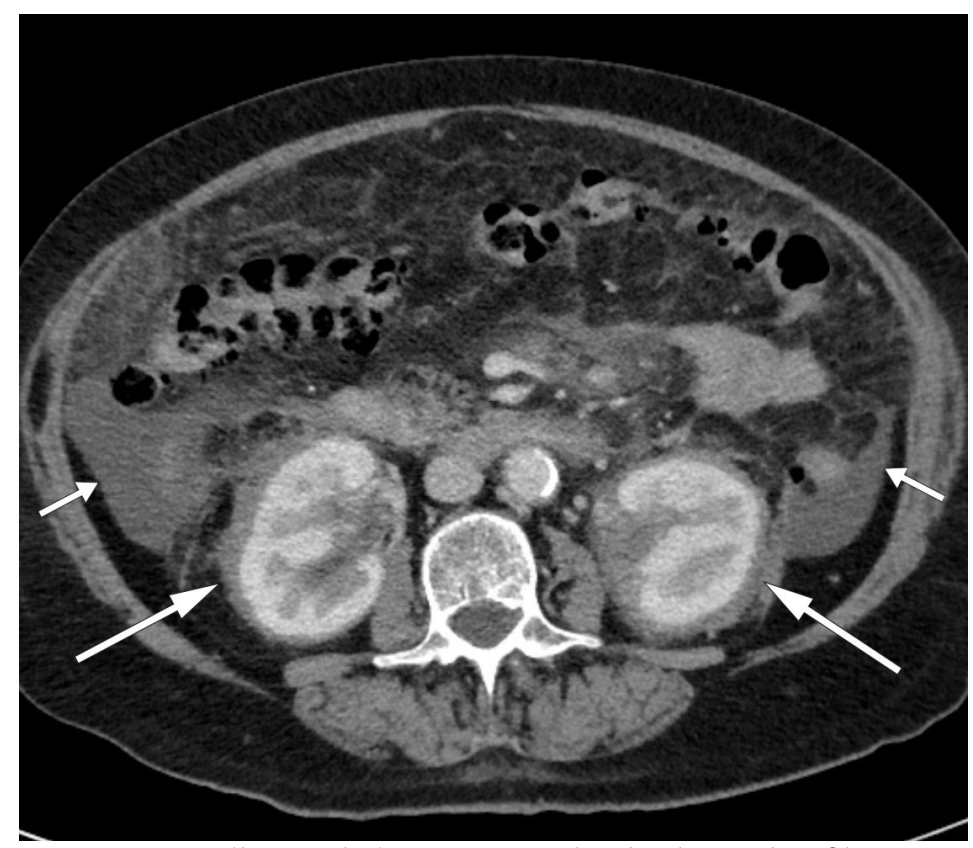

Figur 1 Ascites (korte piler) og symmetrisk, ødemlignende infiltrasjon i perirenalt vev (lange piler) forenlig med hårete nyrer (hairy kidneys) på CT abdomen.

Fortykkelse av pleura og perikard kan påvises ved radiologiske undersøkelser eller ekkokardiografi og kan ses ved for eksempel infeksjoner, bindevevssykdommer, mesoteliom, lymfom eller metastaser $(7,8)$. Affeksjon av både pleura, perikard og peritoneum gjør at systemisk sykdom må mistenkes.

Hårete nyrer er uttrykk for retroperitoneal fibrose som infiltrerer perirenalt fettvev, med fortykkelse av nyrekapslene. Ved funn av retroperitoneal fibrose er den som regel lokalisert rundt abdominalaorta og iliaca communis-karene, men den kan også være mer utbredt (9). Retroperitoneal fibrose er i over 70 \% av tilfellene idiopatisk (10), mens de resterende kan skyldes for eksempel medikamenter, malignitet, infeksjoner, kirurgi, stråling, amyloidose og histiocytoser (9). Idiopatisk retroperitoneal fibrose klassifiseres ofte som en kronisk periaortitt, enten isolert eller assosiert med andre autoimmune sykdommer eller immunglobulin $\mathrm{G}_{4}$ (IgG4)-relatert sykdom (11). Symptomene kan være vage og lite spesifikke. Det typiske er korsryggssmerter, eventuelt med utstråling til lysken, ledsaget av vekttap, redusert appetitt, utmattelse, feber, oppkast og kvalme. Ikke rent sjelden - som hos vår pasient - oppdages tilstanden tilfeldig når abdomen undersøkes radiologisk. Men i vårt tilfelle var infiltrasjonen mer utbredt enn det som er vanlig ved retroperitoneal fibrose.

Det kliniske bildet var nå dominert av feber, tørrhoste, dyspné og ascites. Blodprøvene ved innleggelsen ved universitetssykehuset viste forhøyede inflammasjonsparametere med Creaktivt protein (CRP) på $105 \mathrm{mg} / \mathrm{l}$ (referanseområde $\leq 5$ ), senkningsreaksjon (SR) $98 \mathrm{~mm} / \mathrm{t}$ (1-28) og leukocytter 12,8 $\cdot 10^{9} / \mathrm{l}(3,7-10,0)$. Differensialtelling av leukocytter viste $89 \%(47-75)$ nøytrofile celler, 7 \% (21-43) lymfocytter, $3 \%$ (4-14) monocytter, $1 \%(1-4)$ eosinofile celler og o \% (o-2) basofile celler. Hemoglobin var 9,7 g/10o $\mathrm{ml}(11,7-15,3)$, trombocytter $565 \cdot 10^{9} / 1$ (145-390), kreatinin $68 \mu \mathrm{mol} / \mathrm{l}$ (45-90) med estimert glomerulær filtrasjonshastighet (eGFR) $80 \mathrm{ml} / \mathrm{min} / 1,73 \mathrm{~m}^{2}$, protrombintid (PT)-INR 1,2 (o,8-1,2) og albumin $22 \mathrm{~g} / \mathrm{l}$ (36-47). Kalium var lett redusert til 3,1 mmol/l (3,5-4,4), mens både natrium og kalsium var innenfor referanseområdet med verdier på henholdsvis 140 mmol/l (137-145) og 2,29 mmol/l $\left(2,15^{-2,51)}\right.$. Det var sannsynlig at dette dreide seg om en systemsykdom med affeksjon av en rekke organer og organsystemer. En omfattende utredning ble derfor initiert.

I tillegg til de perinefriske forandringene var det påfallende funn på CT thorax (fig 2) og helkroppsscintigrafi (fig 3). Som et bifunn ble det også funnet en liten lungeembolus. MR hjerte og ekkokardiografi påviste lokalt fortykket perikard, mens MR caput og orbita viste normale funn. Abdominal paracentese viste CD68-positive og CD1a-negative makrofager og ingen tegn til mikrober. I ascitesvæsken, som var gjennomskinnelig og gul, var albuminnivået $13 \mathrm{~g} / \mathrm{l}$ og proteinkonsentrasjonen $24 \mathrm{~g} / \mathrm{l}$ (under $30 \mathrm{~g} / \mathrm{l}$ tydet på transudat). 
Serum-ascites-albumin-gradienten (SAAG) var $9 \mathrm{~g} / \mathrm{l}$, forenlig med at årsaken til ascites ikke var portal hypertensjon. Leukocytter i ascitesvæsken var $0,2 \mathrm{O} \cdot 10^{9} / 1$, noe som utelukket spontan bakteriell peritonitt. På blodutstryk var det granulocytose og trombocytose, mens benmargsutstryk viste reaktiv/normal benmarg. Benmargsbiopsi viste noen svakt reaktive megakaryocytter, og biopsier fra femur påviste kun osteomyelosklerose. Biopsi fra perinefrisk vev viste fibrose og histiocytter som var positive for CD68 og negative for CD1a, samt en uspesifikk reaksjon for S1oo-proteiner. Genetisk testing for BRAF-mutasjon var negativ.

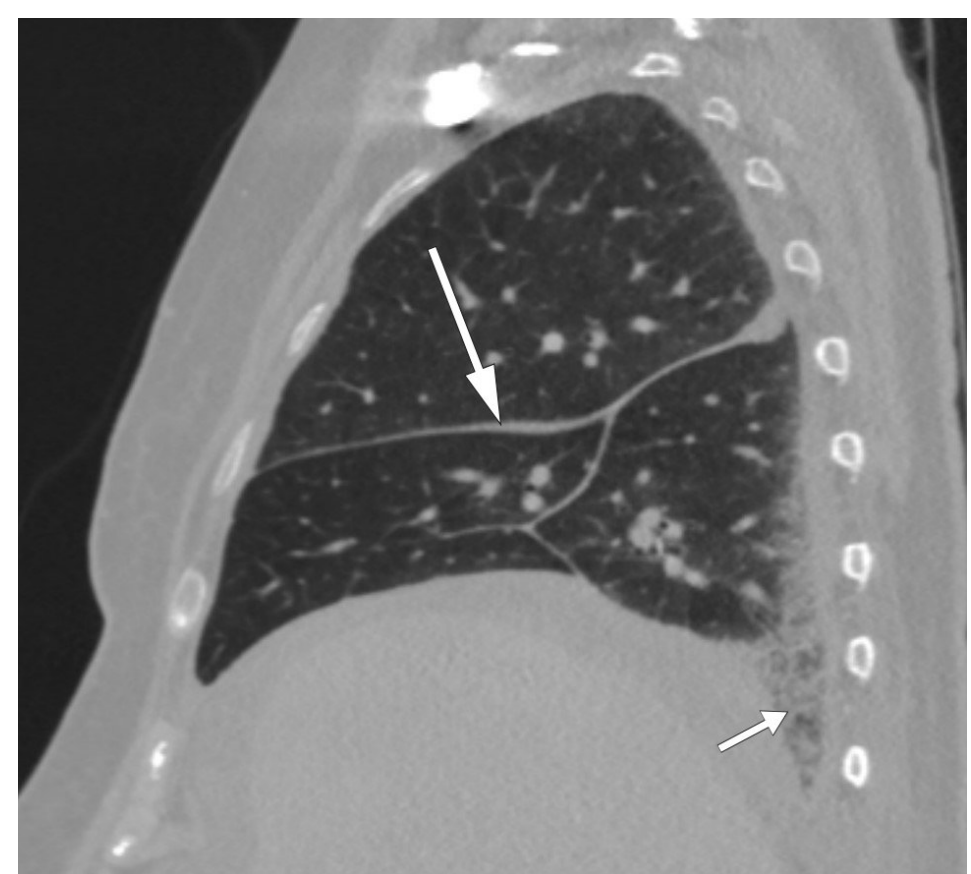

Figur 2 CT thorax som viser jevn fortykkelse av interlobulcere spalter (lang pil) og retikulcere forandringer basalt i høyre lunges underlapp (kort pil). 

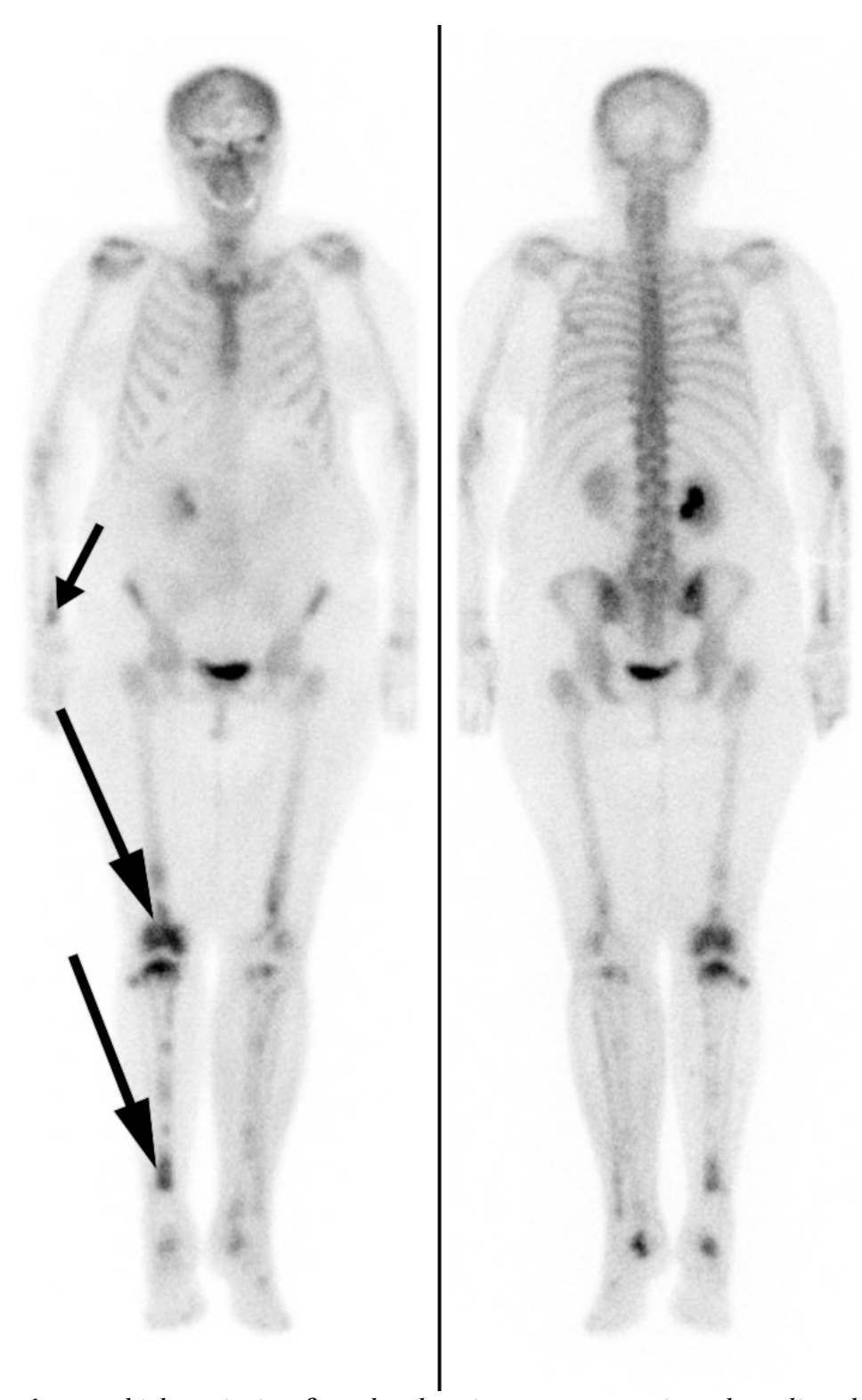

Figur 3 Skjelettscintigrafi med technetium-99 $\mathrm{m}$ som viser økt radionuklidopptak i begge underekstremiteter, scrlig i diafyscere og metafyscere områder på høyre side (lang pil). Legg også merke til økt opptak i distale radius på høyre side (kort pil).

Kort oppsummert hadde pasienten allmennsymptomer, luftveissymptomer og ascites. Inflammasjonsparametrene var forhøyede, hun hadde anemi og hypoalbuminemi. Radiologisk var det funn perirenalt, i lungene og skjelettet, mens makrofager og histiocytter ble påvist henholdsvis i ascitesvæsken og i perirenalt vev. Samtidig måtte hennes komorbiditet med essensiell trombocytose tas i betraktning. Muligheten for at den aktuelle tilstanden kunne være relatert til en JAK2-V617F-positiv myeloproliferativ neoplasi ble vurdert. Hun kunne også ha en uklassifisert myeloproliferativ neoplasi (MPN) der den essensielle trombocytosen hadde transformert til myelofibrose, akutt myeloid leukemi eller myelodysplastisk syndrom, uten at det entydig kunne forklare tilstanden. Utbredt lymfom og IgG4-relatert sykdom samt medikamentbivirkninger ble også vurdert, men det ble ikke funnet holdepunkter for disse. Videre var langerhanscellehistiocytose en mulig forklaring på histiocyttene, men de uttrykte ikke CD1a, som langerhansceller gjør.

Immunhistokjemi og immuncytokjemi er supplerende undersøkelser til henholdsvis histologisk og cytologisk mikroskopisk undersøkelse av vev. Metoden brukes for å påvise spesifikke proteiner i cellen eller på cellemembranen, og er viktig innenfor diagnostikken av cancer, infeksjonssykdom og immunologisk sykdom. CD68 uttrykkes av monocytter og vevsmakrofager (12), CD1a brukes ofte som kjennetegn på dendrittiske celler (13), mens S10o utgjør en gruppe proteiner som er viktige innenfor inflammatoriske sykdommer, kreft og immunforsvaret (14). 
Påvisning av eventuelle mutasjoner i cellene kan også være avgjørende, både diagnostisk og behandlingsmessig. Mutasjon i BRAF-genet fører for eksempel til en aktivering av en intracellulær signalkaskade som er assosiert med en rekke krefttyper, eksempelvis malignt melanom (15).

Flere differensialdiagnoser ble diskutert. Allerede da tilfellet ble drøftet med universitetssykehus første gang, ble det fra radiolog, grunnet hårete nyrer, påpekt muligheten for Erdheim-Chesters sykdom (ECD). Basert på kliniske funn, blodprøver, radiologi og histologi pekte dette seg ut som den mest sannsynlige diagnosen. Det ble startet behandling med interferon- $\alpha$, men behandlingen hadde ingen effekt på sykdomsaktivitet, og pasienten utviklet bivirkninger i form av influensalignende sykdom. Hun ble innlagt på et annet universitetssykehus, hvor det ble satt i gang kombinasjonsbehandling med mTOR-hemmeren sirolimus og prednisolon. Allerede etter få dager var det klinisk bedring, og fire måneder senere var hun betraktelig bedre. Feberen og hosten gikk tilbake, mens SR, leukocytter, hemoglobin og albumin var normalisert. På dette tidspunktet var det også foretatt PET-CT som viste regresjon av de patologiske funnene. Pasienten følges nå med jevnlige kontroller.

\section{Diskusjon}

Erdheim-Chesters sykdom er en sjelden ikke-langerhanscellehistiocytose som karakteriseres av infiltrasjon av CD68-positive og CD1a-negative histiocytter i lange rørknokler og retroperitoneum. Flere organer kan være affisert, og etiologien er ukjent. Mutasjoner i BRAF-V6ooE $(16,17)$, NRAS og PIK 3 CA (18), som alle er protoonkogener involvert i karsinogenesen av flere kreftformer, kan være viktige. Det indikerer at sykdommen muligens representerer en malign tilstand (19). Det har også vært diskutert om immunmedierte mekanismer, cytokiner og kjemokiner kan føre til akkumulering av histiocytter i de affiserte vevene og at det indikerer at en inflammatorisk komponent er involvert i utviklingen av sykdommen (20-22).

Histiocytosene kan inndeles i fem grupper, og fellesnevneren er akkumulering av celler som stammer fra dendrittiske celler eller makrofager. Mer enn 100 ulike typer er beskrevet, med stor variasjon i symptomer, funn og histologi (23). Erdheim-Chesters sykdom tilhører, sammen med langerhanscellehistiocytose, den såkalte L-gruppen. I den samme gruppen finnes en kombinert type og en type som ut fra karakteristika ved cellene verken tilhører Erdheim-Chesters sykdom eller Langerhanscellehistiocytose.

Diagnosen Erdheim-Chesters sykdom er basert på kliniske, radiologiske og histologiske funn. Det vanligste er affeksjon av skjelettet, sentralnervesystemet, nyrene og det kardiovaskulære systemet $(24,25)$. Infiltrasjon i orbita er også beskrevet, for eksempel i en kasuistikk i Tidsskriftet fra 2014 (26). Symptomene avhenger av organaffeksjon, men det typiske er skjelett- eller leddsmerter, dyspné, hoste, eksoftalmus eller xantomer samt synsforstyrrelser, ataksi, hodepine eller andre nevrologiske symptomer. Kardial affeksjon er ofte asymptomatisk, men det kan ha store konsekvenser. Perikardsykdom som perikarditt, perikardvæske eller tamponade rammer opp mot $45 \%$ av pasientene. Det er mer uvanlig med histiocyttinfiltrasjon i myokard og koronarkar, som kan føre til iskemi, klaffefeil eller ledningsforstyrrelser (27). Vår pasient hadde fortykket perikard, visualisert både på CT thorax, MR hjerte og ekkokardiografi, men ingen perikardvæske og god hjertefunksjon for $\emptyset$ vrig.

Symmetrisk osteosklerose i diafysene og metafysene i lange rørknokler, inflammatoriske forandringer rundt aorta (coated aorta) og perirenal infiltrasjon av histiocytter (hårete nyrer) er typiske radiologiske funn $(25,28,29)$. Sistnevnte er nærmest patognomonisk for tilstanden og en viktig grunn til at diagnosen tidlig ble mistenkt hos vår pasient. Det histologiske bildet er karakterisert av lipidfylte såkalte skumhistiocytter, ofte kombinert med fibrose. Immunhistokjemisk vil de være positive for CD68, CD163 og faktor XIIIa, og i noen tilfeller for S10o, som skiller dem fra histiocytter ved en del andre tilstander. De vil også være negative for CD1a og langerin (CD207) (27). 
I tillegg til flere av de typiske funnene ved sykdommen, hadde vår pasient ascites som et fremtredende symptom. Dette er sjelden ved denne tilstanden, og årsaken her var sannsynligvis hypoalbuminemi sekundært til langvarig inflammasjon og lokal inflammasjon intraabdominalt.

På grunn av den lave insidensen og prevalensen av sykdommen mangler det store, randomiserte, kontrollerte studier av behandlingsmulighetene. Basert på studiene som er utført, er førstelinjebehandlingen interferon (IFN)- $\alpha$-2a eller pegylert interferon- $\alpha$ (PEG-IFN$\alpha)$. Kjemoterapi, anticytokinrettet terapi, glukokortikoider eller BRAF-hemmeren vemurafenib er andre alternativer. Sistnevnte er særlig aktuelt ved påvist BRAF-mutasjon. Stråling og kirurgi kan være aktuelt ved palliativ behandling (27).

Med tanke på at ascites var et hovedfunn, beskriver vår kasuistikk en uvanlig presentasjon av Erdheim-Chesters sykdom. For å sette korrekt diagnose er det viktigste å tenke på muligheten for sykdommen, særlig ved karakteristiske funn ved radiologiske undersøkelser.

\section{LITTERATUR:}

1. Goldhaber SZ. Risk factors for venous thromboembolism. J Am Coll Cardiol 2010; 56:1 - 7 . [PubMed][CrossRef]

2. Lijfering WM, Rosendaal FR, Cannegieter SC. Risk factors for venous thrombosis - current understanding from an epidemiological point of view. Br J Haematol 2010; 149: 824 - 33 . [PubMed][CrossRef]

3. Landolfi R, Marchioli R, Patrono C. Mechanisms of bleeding and thrombosis in myeloproliferative disorders. Thromb Haemost 1997; 78: 617 - 21. [PubMed]

4. Kahn SR, Galanaud JP, Vedantham S et al. Guidance for the prevention and treatment of the postthrombotic syndrome. J Thromb Thrombolysis 2016; 41: 144 - 53. [PubMed][CrossRef]

5. Campbell PJ, Green AR. The myeloproliferative disorders. N Engl J Med 20o6; 355: 2452 - 66.

[PubMed][CrossRef]

6. Faderl S, Talpaz M, Estrov Z et al. The biology of chronic myeloid leukemia. N Engl J Med 1999;341: 164-72. [PubMed][CrossRef]

7. Downer NJ, Ali NJ, Au-Yong ITH. Investigating pleural thickening. BMJ 2013; 346: e8376.

[PubMed][CrossRef]

8. Imazio M, Gaita F. Diagnosis and treatment of pericarditis. Heart 2015; 101: 1159 - 68.

[PubMed][CrossRef]

9. Vaglio A, Salvarani C, Buzio C. Retroperitoneal fibrosis. Lancet 2006;367: 241 - 51.

[PubMed][CrossRef]

10. Cronin CG, Lohan DG, Blake MA et al. Retroperitoneal fibrosis: a review of clinical features and imaging findings. AJR Am J Roentgenol 2008; 191: 423 -31. [PubMed][CrossRef]

11. Urban ML, Palmisano A, Nicastro M et al. Idiopathic and secondary forms of retroperitoneal fibrosis: a diagnostic approach. Rev Med Interne 2015; 36: 15 - 21. [PubMed][CrossRef]

12. Holness CL, Simmons DL. Molecular cloning of CD68, a human macrophage marker related to lysosomal glycoproteins. Blood 1993; 81:1607-13. [PubMed]

13. Gogolak P, Rethi B, Szatmari I et al. Differentiation of CD1a- and CD1a+ monocyte-derived dendritic cells is biased by lipid environment and PPARgamma. Blood 2007; 109: 643 - 52. [PubMed][CrossRef]

14. Wheeler LC, Donor MT, Prell JS et al. Multiple Evolutionary Origins of Ubiquitous Cu2+ and Zn2+ Binding in the S10o Protein Family. PLoS One 2016; 11: eo164740. [PubMed][CrossRef]

15. Davies H, Bignell GR, Cox C et al. Mutations of the BRAF gene in human cancer. Nature 2002; 417: 949-54. [PubMed][CrossRef]

16. Haroche J, Charlotte F, Arnaud L et al. High prevalence of BRAF V6ooE mutations in Erdheim- 
Chester disease but not in other non-Langerhans cell histiocytoses. Blood 2012; 120: 2700 -3. [PubMed][CrossRef]

17. Cangi MG, Biavasco R, Cavalli G et al. BRAFV6ooE-mutation is invariably present and associated to oncogene-induced senescence in Erdheim-Chester disease. Ann Rheum Dis 2015; 74: 1596 - 602. [PubMed][CrossRef]

18. Emile JF, Diamond EL, Hélias-Rodzewicz Z et al. Recurrent RAS and PIK3CA mutations in ErdheimChester disease. Blood 2014; 124:3016 - 9. [PubMed][CrossRef]

19. Haroche J, Cohen-Aubart F, Charlotte F et al. The histiocytosis Erdheim-Chester disease is an inflammatory myeloid neoplasm. Expert Rev Clin Immunol 2015; 11: 1033 - 42. [PubMed][CrossRef] 20. Stoppacciaro A, Ferrarini M, Salmaggi C et al. Immunohistochemical evidence of a cytokine and chemokine network in three patients with Erdheim-Chester disease: implications for pathogenesis. Arthritis Rheum 2006; 54: 4018 - 22. [PubMed][CrossRef]

21. Arnaud L, Gorochov G, Charlotte F et al. Systemic perturbation of cytokine and chemokine networks in Erdheim-Chester disease: a single-center series of 37 patients. Blood 2011; 117: 2783 - 90. [PubMed][CrossRef]

22. Cavalli G, Biavasco R, Borgiani B et al. Oncogene-induced senescence as a new mechanism of disease: the paradigm of erdheim-chester disease. Front Immunol 2014; 5: 281. [PubMed][CrossRef]

23. Emile JF, Abla O, Fraitag S et al. Revised classification of histiocytoses and neoplasms of the macrophage-dendritic cell lineages. Blood 2016; 127: 2672 - 81. [PubMed][CrossRef]

24. Campochiaro C, Tomelleri A, Cavalli G et al. Erdheim-Chester disease. Eur J Intern Med 2015; 26: 223 9. [PubMed][CrossRef]

25. Haroche J, Arnaud L, Cohen-Aubart F et al. Erdheim-Chester disease. Rheum Dis Clin North Am 2013; 39: 299-311. [PubMed][CrossRef]

26. Midtvedt $\emptyset$, Gran JT, Solheim H et al. En mann i 40-årene med hevelse i begge øyehuler. Tidsskr Nor Legeforen 2014; 134:1472 - 6. [PubMed][CrossRef]

27. Diamond EL, Dagna L, Hyman DM et al. Consensus guidelines for the diagnosis and clinical management of Erdheim-Chester disease. Blood 2014; 124: 483 - 92. [PubMed][CrossRef]

28. Cives M, Simone V, Rizzo FM et al. Erdheim-Chester disease: a systematic review. Crit Rev Oncol Hematol 2015; 95: 1 - 11. [PubMed][CrossRef]

29. Antunes C, Graça B, Donato P. Thoracic, abdominal and musculoskeletal involvement in ErdheimChester disease: CT, MR and PET imaging findings. Insights Imaging 2014; 5: 473-82.

[PubMed][CrossRef]

Publisert: 6. juni 2018. Tidsskr Nor Legeforen. DOI: 10.4045/tidsskr.17.0817

Mottatt 4.10.2018, første revisjon innsendt 11.3.2018, godkjent 15.3.2018.

(C) Tidsskrift for Den norske legeforening 2020. Lastet ned fra tidsskriftet.no 